\title{
Hypoxia-Induced Aquaporin-3 Changes Hepatocellular Carcinoma Cell Sensitivity to Sorafenib by Activating the PI3K/Akt Signaling Pathway [Retraction]
}

Malale K, Fu J, Qiu L, Zhan K, Gan X, Mei Z. Cancer Manag Res. 2020;12:4321-4333.

The Editor and Publisher of Cancer Management and Research wish to retract the published article. Concerns were raised regarding the alleged duplication of Western Blot images in Figures 1D, 3A, 5A and 5B. The authors responded to our initial queries but were unable to provide a satisfactory explanation for the alleged duplication and could not provide satisfactory original data for their study. The Editor advised for the article to be retracted.
The authors wish to apologise for this error.

Our decision-making was informed by our policy on publishing ethics and integrity and the COPE guidelines on retraction.

The retracted article will remain online to maintain the scholarly record, but it will be digitally watermarked on each page as "Retracted".

\section{Publish your work in this journal}

Cancer Management and Research is an international, peer-reviewed open access journal focusing on cancer research and the optimal use of preventative and integrated treatment interventions to achieve improved outcomes, enhanced survival and quality of life for the cancer patient.
The manuscript management system is completely online and includes a very quick and fair peer-review system, which is all easy to use. Visit http://www.dovepress.com/testimonials.php to read real quotes from published authors. 